\title{
Vedolizumab: a novel medical intervention in the treatment of primary sclerosing cholangitis
}

\author{
Donevan Westerveld, ${ }^{1}$ Joseph Grajo, ${ }^{2}$ Lars Beattie, ${ }^{3}$ Sarah Glover ${ }^{4}$
}

'Department of Internal Medicine, University of Florida, Gainesville, Florida, USA

${ }^{2}$ Department of Radiology, University of Florida College of Medicine, Gainesville, Florida, USA

${ }^{3}$ Department of Emergency Medicine, University of Florida College of Medicine, Gainesville, Florida, USA

${ }^{4}$ Department of

Gastroenterology, University of Florida College of Medicine, Gainesville, Florida, USA

\section{Correspondence to}

Dr Donevan Westerveld, dwesterveld@ufl.edu

Accepted 27 April 2017

\section{CrossMark}

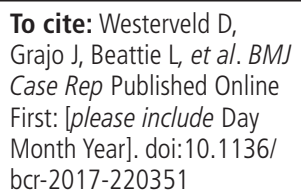

To cite: Westerveld $D$, Grajo J, Beattie L, et al. BMJ Case Rep Published Online First: [please include Day Month Year]. doi:10.1136/ bcr-2017-220351

\section{DESCRIPTION}

Primary sclerosing cholangitis (PSC) is an idiopathic and insidious cholestatic liver disease characterised by persistent inflammation of the biliary tree, leading to fibrosis and stricturing. ${ }^{1}$ Often associated with inflammatory bowel disease, pathogenesis may be related to activated intestinal T-cells expressing the integrin cell surface receptor $\alpha_{4} \beta_{7}$. These T-cells are recruited to the liver parenchyma resulting in persistent biliary inflammation. ${ }^{1}$ Patients typically remain asymptomatic until a diagnosis is attained by detection of elevated liver enzymes. ${ }^{2}$ No effective medical management exists, and the progressive fibrotic nature of the disease usually results in the necessity of liver transplantation.

We present a case of a male in his 40 s with a 30 -year history of ulcerative colitis and newly diagnosed PSC, who demonstrated an improvement in inflammation and stricturing of the biliary tree with vedolizumab (figure 1). On routine follow-up our patient was found to have an elevated alkaline phosphatase of 225 $\mathrm{IU} / \mathrm{L}$ (alanine transaminase (ALT) $121 \mathrm{IU} / \mathrm{L}$; aspartate transaminase (AST) $69 \mathrm{IU} / \mathrm{L}$ ). Magnetic resonance cholangiopancreatography (MRCP) revealed stricturing and narrowing of the left and right intrahepatic ducts, findings consistent with PSC. A trial of ursodiol did not improve his clinical course. Treatment with vedolizumab was initiated with a standard loading dose of $300 \mathrm{mg}$ at 0,2 and 6 weeks followed by every 8 weeks thereafter. Thirteen months

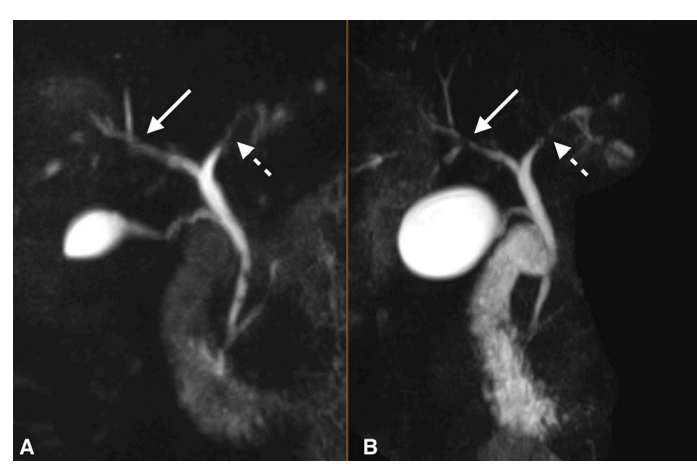

Figure 1 T2-weighted three-dimensional maximum intensity projection coronal images with fat saturation from prior to treatment induction (B) and 13 months following induction (A) demonstrate improvement in the strictures of the intrahepatic biliary tree, particularly the right hepatic duct and its segmental branches (solid arrows). The left hepatic duct also shows decreased irregular luminal narrowing (dashed arrows) following vedolizumab therapy. Both images are shown at equal levels as they are centred at the hepatic hilum with.

\section{Learning points}

- In primary sclerosing cholangitis, it is believed that intestinal T-cells express the cell surface integrin $\alpha_{4} \beta_{7}$ and are recruited to the hepatic parenchyma. Once in the hepatic tissue, these T-cells will bind to their ligand, mucosal addressin cell adhesion molecule 1. This binding of T-cell to its ligand has been associated with continued inflammation and subsequent fibrosis.

- Treatment with vedolizumab, a monoclonal antibody that selectively blocks gut lymphocyte trafficking, may improve or slow progression of inflammation and fibrosis of the biliary tree.

- Patients may be asymptomatic when initially diagnosed with primary sclerosing cholangitis (PSC). However, if symptoms do occur they are predominantly abdominal pain, pruritus, and fatigue. Standard loading dose of vedolizumab of $300 \mathrm{mg}$ at 0,2 and 6 weeks followed by every 8 weeks over a period of 1 year, improved the associated PSC symptoms of pruritus and abdominal pain in our patient.

following induction of treatment, a follow-up MRCP demonstrated improvement in stricturing, and alkaline phosphatase was 127 IU/L (ALT 64 IU/L; AST 42 $\mathrm{IU} / \mathrm{L}$ ). A humanised monoclonal antibody, vedolizumab specifically recognised $\alpha_{4} \beta_{7}$ heterodimer and selectively blocking gut lymphocyte trafficking. ${ }^{3}$ This inhibition of lymphocytic homing may aid in slowing or reverse the detrimental fibrotic nature of PSC.

Contributors DW, JG, LB and SG contributed to this project as a team; portions were written and edited by each member of the team multiple times. SG, the attending physician, gave the final approval to this work.

Competing interests None declared.

Patient consent Obtained.

Provenance and peer review Not commissioned; externally peer reviewed.

(c) BMJ Publishing Group Ltd (unless otherwise stated in the text of the article) 2017. All rights reserved. No commercial use is permitted unless otherwise expressly granted.

\section{REFERENCES}

1 Lazaridis KN, LaRusso NF. Primary sclerosing cholangitis. N Engl J Med 2016:375:1161-70.

2 Kaplan GG, Laupland KB, Butzner D, et al. The burden of large and small duct primary sclerosing cholangitis in adults and children: a population-based analysis. Am J Gastroenterol 2007;102:1042-9.

3 Feagan BG, Rutgeerts P, Sands BE, et al. Vedolizumab as induction and maintenance therapy for ulcerative colitis. $N$ Eng/ J Med 2013;369:699-710. 
Copyright 2017 BMJ Publishing Group. All rights reserved. For permission to reuse any of this content visit http://group.bmj.com/group/rights-licensing/permissions.

BMJ Case Report Fellows may re-use this article for personal use and teaching without any further permission.

Become a Fellow of BMJ Case Reports today and you can:

- Submit as many cases as you like

- Enjoy fast sympathetic peer review and rapid publication of accepted articles

Access all the published articles

- Re-use any of the published material for personal use and teaching without further permission

For information on Institutional Fellowships contact consortiasales@bmjgroup.com

Visit casereports.bmj.com for more articles like this and to become a Fellow 